\title{
ПОЛІтоЛОГІя
}

УДК 94+930.2]323.174(477:(470+571))

DOI https://doi.org/10.32837/apfs.v0i29.966

\author{
A.С. Баскакова \\ ORCID ID: https://orcid.org/0000-0001-9662-0789 \\ третій секретар \\ Міністерства закордонних справ України
}

\section{КРИМСЬКА КРИЗА ТА РОСІЙСЬКО-УКРАЇНСЬКА ВІЙНА: ПОГЛЯД ІЗ ПОЗИЦІї ПОЛІТИЧНОГО НЕОРЕАЛІЗМУ}

Постановка проблеми. Кримська криза 2014 року та початок російсько-українського збройного протистояння є предметом багатьох досліджень у міжнародно-політичній науковій думці, більшість з них присвячені аналізу хронології подій, вивченню міжнародної реакції та розробці ймовірних сценаріїв подальшого розвитку ситуації. Проте дуже мало доробків, предметом яких виступає пошук причин агресивної політики РФ щодо України, більш того, автори не намагаються використати теоретико-концептуальний каркас міжнародно-політичної науки для пояснення причин територіальної експансії Росії стосовно України.

Аналіз останніх досліджень і публікацій. Для вирішення поставлених завдань було досліджено наукові здобутки представників двох теорій. По-перше, політичний неореалізм - основоположник К. Уолтц [3] та праці Дж. Міршаймера [4]. По-друге, теорія балансу загроз - А. Бок, Ф. Планк, І. Хеннеберг [2]. У вітчизняній науковій думці комплексного аналізу проблеми з точки зору політичного неореалізму немає. Тому постала проблема концептуалізації Кримської кризи та російсько-українського збройного протистояння, що і $є$ предметом нашого наукового доробку.

Мета статті - дослідити Кримську кризу та початок українсько-російського збройного протистояння через теоретико-концептуальний та методологічний інструментарій такого наукового напряму в міжнародно-політичній науці, як політичний неореалізм.

Виклад основного матеріалу дослідження. Після возз'єднання Німеччини стало зрозуміло, що на світ чекають глобальні геополітичні трансформації. Так, наближався процес розпаду СРСР та остаточний крах біполярної системи міжнародних відносин. Саме в той період лунали заяви європейських лідерів про те, що в зв'язку з тим, що об’єднання Східної та Західної Німеччини відбулось мирним шляхом, то вони беруть на себе відповідальність за те, що жодна країна із соціа- лістичного табору не буде включена в західноєвропейський інтеграційний простір. Тим не менш 3 розпадом Організації Варшавського Договору та СРСР колишні країни соціалістичного табору оголосили про свої наміри щодо вступу в НАТО та $\mathrm{CC}$, що призвело до розширення цих організацій на Схід. Особливо різкою реакція Москви була на прийняття країн Балтії до лав НАТО, розуміючи, що у Грузії та України є також перспектива прийняття в Альянс, Росія була вимушена діяти негайно, що призвело до 5-денної війни у серпні 2008 року на терені Грузії. Такими діями Росія продемонструвала свої чіткі наміри захищати зону свого геополітичного впливу, байдуже якими засобами: насильницькими чи мирними. Перевагу, звісно, Росія надає "hard power". Окупація частини території України, відкрите російсько-українське збройне протистояння на території нашої держави свідчить про те, що Білокамінна сприймає інтеграцію України в НАТО та ЄС як пряму загрозу інтересам іï національної безпеки. Тому єдиний вихід із ситуації вбачається у захисті цих інтересів шляхом вжиття насильницьких засобів протидії як євроінтеграційній політиці України, так і намірам НАТО та ЄС наблизитись впритул до кордонів Росії.

Пригадаємо події 2013 року. В листопаді 2013 року Президент України В. Янукович, який переміг на президентських виборах у 2010 році, відмовився підписувати Угоду про асоціацію України з СС. Таке рішення було обгрунтоване бажанням більш тісної співпраці з Росією. Це викликало обурення у політично свідомого населення України, що призвело до народного вибуху в столиці, а згодом і до подій, які отримали назву Революція Гідності. В грудні 2013 року В. Путін намагався вжити заходів, аби В. Янукович зміг зберегти за собою посаду президента, зокрема, грав на енергетичних питаннях на кшталт зниження цін на енергоносії або викупу українського боргу за газ. В лютому в результаті кривавих подій у столиці України - Києві було повалено проросійський режим В. Януковича, а до влади прийшов 
прозахідний уряд П. Порошенка, якого підтримали і США, і Західна Європа.

Росія не могла грати роль спостерігача за подіями, адже Революція Гідності та прихід до влади прозахідного режиму не входили в її плани щодо контролю за Україною, тому вибрала для себе новий сценарій захисту власних інтересів: поступове втягування України у стан нестабільності за рахунок матеріально-технічної та військової підтримки російськомовних громадян України переважно на Сході нашої держави, які були не задоволені політикою українізації тощо. В березні 2014 року Росія анексувала Кримський півострів, розпочався збройний наступ вглиб Донбасу. Російсько-українська війна триває сьомий рік і перспективи миру неоднозначні.

3 метою проведення більш глибшого аналізу Кримської кризи та початку українсько-російського збройного протистояння спробуємо використати теоретико-концептуальний та методологічний інструментарій такого наукового напряму в міжнародно-політичній науці, як політичний неореалізм.

Основоположником політичного неореалізму вважають Кеннета Уолтца. Засадничі ідеї цього напряму висвітлені у його книзі «Теорія міжнародної політики» (1979) [3]. Тим не менш його погляди піддавались та продовжують піддаватись критиці, особливо у питанні про довговічність біполярної системи міжнародних відносин. Проте, незважаючи на наявну критику, розроблена К. Уолтцом, теорія може надати нам практичні інструменти для проведення аналізу та оцінки подій 2014 року. Тому ми будемо використовувати ключові положення цієї теорії, її концептуальні засади для вивчення зазначеної в статті проблеми.

Варто зауважити, що різні вчені використовували неореалістичні вихідні концептуальні положення для пояснення загострення відносин між Росією та Україною, причинами якого стали окупація Кримського півострову Російською Федерацією та початок збройного російсько-українського протистояння на Сході нашої держави. Такі вчені, як А. Бок, Ф. Планк та I. Хеннеберг, використовували нереалістичну теорію «балансу загроз» для вивчення сприйняття Москвою загроз її інтересам національної безпеки [2]. Саме з точки зору цієї теорії анексію Криму - дії РФ, які призвели до порушення норм міжнародного права, не можна абсолютно інтерпретувати як прояв неоімперіалістичних амбіцій Москви. Адже поведінка кожної держави визначається загрозами з боку інших держав або міждержавних об'єднань [2]. Держави балансуватимуть не 3 іншими державами, що набирають сили, тобто нарощують свою політичну, економічну, військову потужність, а з тими, дії яких несуть загрозу для інтересів національної безпеки. У своїх діях Москва виходить з того, що
США та Західна Європа використовують НАТО не як політичний інструмент для розв'язання кризових ситуацій, а як військовий, тому розширення Альянсу впритул до кордонів Росії та розміщення військових баз НАТО на терені цих держав сприймається як загроза національній безпеці Росії, безпеці їі кордонів. Єдиним виходом для неї вбачається протидія такій політиці Альянсу будьякими засобами, в тому числі й насильницькими. Більш того, своїми діями Москва хоче породити низку нових загроз для США та Західної Європи (на кшталт підриву енергетичної безпеки країн Західної Європи або породження дуги нестабільності на східних кордонах $\mathrm{CC)} \mathrm{та} \mathrm{зберегти} \mathrm{баланс}$ загроз, виходячи із власних національних інтересів. Прагнення зберегти баланс загроз у 2014 році було реалізоване в її прагматичних кроках: анексія Криму та початок російсько-української війни на Сході нашої держави.

Дж. Міршаймер стверджує, що Кримська криза в Україні та події на Сході Української держави - провина Заходу [4]. Адже саме головною причиною кризи 2014 року стало розширення HATO на Схід та прагнення Вашингтона вивести Україну з орбіти Москви, щоб інтегрувати ї̈ в західноєвропейський політичний, військовий, економічний та культурний простір [4]. Тому агресивна поведінка Москви щодо України не $є$ дивною. Адже поглинання України євро- та євроатлантичними структурами призвело б до остаточного переформатування зон геополітичної відповідальності у Східній Європі, поступово витісняючи Росію із зони її регіонального впливу та позбавляючи її можливостей впливу на внутрішні процеси в країнах Східноєвропейського простору. Отже, ймовірний вступ України до ЄС та НАТО ставив під загрозу основні стратегічні інтереси Росії в регіоні [4].

Міршаймер називає три чинники, які загострили відносини між Росією та Україною: розширення НАТО, розширення ЄС та просування демократичних цінностей у країни Східної Європи [1]. Саме така констатація про роль Заходу в Кримській кризі та початку відкритого збройного російсько-українського конфлікту викликала активні дебати в академічних колах у глобальному масштабі.

Неореалісти вважають, що Росія своїми агресивними діями намагається стримати розширення НАТО на схід впритул до зони, яка слугує поясом безпеки для Російської Федерації. Україна знаходиться в цій зоні, отже, її територія автоматично стає плацдармом для реалізації політики протидії розширенню НАТО та ЄС з боку РФ. I засобами такої політики виступають окупація частини території України, відкрите збройне протистояння на територіях України, де проживає більшою мірою російськомовне населення 
(схід, південний схід). Для Росії не має значення, на скільки витратними $€$ такі насильницькі засоби, адже для Москви - це питання стратегічної важливості - йдеться про збереження поясу iï безпеки та посилення контролю за простором ï геополітичної відповідальності.

К. Уолтц розглядає міжнародну політику як структуру, за межами якої залишаються питання взаємодії держав у політичній, військовій, економічній та культурній сферах [3, с. 79-80]. Для структури як системи не має значення, якими $е$ ці держави: демократичні чи авторитарні, держави, до влади в яких уряди прийшли законним або революційним шляхом, держави, де ідеологія пануючого режиму визначає стратегію розвитку, чи країни, які будують свої відносини із зовнішнім світом, виходячи із власних прагматичних інтересів. К. Уолтц абстрагується від усіх цих аспектів і не акцентуе увагу на намірах держав розвивати відносини з іншими країнами за шкалою «дружба - ворожнеча» [3, с. 99]. Він вважає, що якщо не брати до уваги ірраціональні елементи аналізу - такі як дружба та ворожнеча, то ми зможемо збагнути, що Росія не є державою-суперницею, яка розпалює війну, щоб задовольнити свої потреби у розширенні власної території за рахунок територій інших держав. Вона просто намагається захистити свої інтереси, адже неможливість ïx забезпечення ставить під загрозу виживання Росії як держави.

К. Уолтц стверджує, що «одиниці міжнародної структури схожі та рівні в різних ситуаціях" [3, с. 94]. Реакції держав однакові, якщо йдеться про поведінку на міжнародній арені або позиціонування, адже дії держав зумовлені рівнем тих дивідендів, які може отримати країна або недоотримати внаслідок ї̈ бездіяльності. Тому реакція Росії на протидію поширенню НАТО на Схід - це не питання автократичних прагнень Путіна або реалізації неоімперських амбіцій Москви. 3 огляду на те, що відповідна система міжнародної політики обов'язково впливає на її структурні одиниці, тобто держави та їх поведінку [3, с. 100], однополярна структура міжнародної політики зобов'язує Росію до військового втручання в Україну. Росія вибудовує свою національну безпеку у відповідності до своїх економічних та геополітичних цілей в Україні. Тут термін «безпека» це широкий термін, який може включати не лише основні питання безпеки, але й може охоплювати більш широку сферу, якщо йдеться, зокрема, про економічний розвиток та ті питання, які є життєво важливими та необхідними для подальшого розвитку держави загалом.

У взаємодії між країнами держава завжди запитує себе, що я отримаю від того чи іншого процесу? Які вигоди? Чи взагалі йдеться тут про вигоди або втрати? I таким чином, в який спосіб можна подолати цей стан незахищеності та ймовірних втрат?

У взаємодії Росії із Західним світом Москва вважає, що в процесі вступу України до НАТО США та Європа отримають більше вигод, а Росія втрачає контроль над зоною своїх інтересів загалом та Україною зокрема. До того ж інструменти її впливу вже не є такими ефективними, якими вони були раніше, зокрема, за часів каденції В. Януковича, відомого своїми проросійськими поглядами. Окрім того, ці інструменти впливу жорстко критикувались та критикуються Заходом (газові, інформаційні війни тощо) й часто використовувались європейськими країнами проти Росії, дії якої засуджувались. Росія, аби зберегти свої вигоди, аби не залишитись на узбіччі зони своїх геополітичних інтересів, вдалася спочатку до превентивних заходів.

У цій системі для Росії єдиний спосіб подолати відчуття власної незахищеності - це утримувати Україну у своїй зоні геополітичних інтересів будьякими можливими засобами, будь-то мирними або насильницькими.

Сучасна система міжнародних відносин анархічна за своєю природою, у системі відсутній такий орган глобального управління, який би брав на себе функції закріплення чітких меж зон геополітичної відповідальності найбільш впливових центрів сили будь-то окремих держав або блоків держав. Тому анархічність міжнародного порядку породжує використання насильницьких методів 3 метою захисту державою інтересів її національної безпеки [3, с. 103]. Саме тому Росія використовує насильницькі методи, адже для неї раціональність військових дій (переваги війни) забезпечити безпеку Росії та її економічні інтереси в Україні більші, ніж ті вигоди, які вона може отримати від миру. Отже, в анархічній системі війна є можливою, вона виступає одним із інструментів захисту інтересів національної безпеки. Коли чергові хвилі розширення НАТО та ЄС кардинально змінюють геополітичний ландшафт Європи, у Росії не залишається іншого вибору - вона намагається захистити своє право на виживання, більш того, прагне довести світові легітимність цього права, обґрунтовуючи свої дії тиском на неї однополярної системи міжнародних відносин та витісненням її з місця у системі геополітичних координат. Отже, сама структура міжнародних відносин зумовлює поведінку окремих держав стосовно інших акторів світової політики.

Лідери західноєвропейських країн розглядають дії Росії щодо України починаючи із 2014 року як прояв ірраціональної поведінки автократичного В. Путіна, який хоче визначати внутрішньо- та зовнішньополітичний курс Української держави, тримати під контролем українську економіку та енергетику та брати під свій контроль 
долю демократії в Україні. Проте представники неореалістичного напряму не розглядають Кримську кризу та російсько-українське збройне протистояння, що триває вже 7 років, як питання протидії формуванню в Україні демократичної політичної системи. Стверджується, що структура міжнародної політики зумовлює спроби Росії змінити саму систему з метою гарантування своїх національних інтересів на території України. Росія у протистоянні з Україною використовує насильницькі засоби на стільки і на скільки це можливо, проте війна не є ціллю Москви, а швидше виступає інструментом забезпечення власних національних інтересів.

$\mathrm{y}$ міжнародно-політичному порядку, де є два або декілька полюсів - центрів сили, структура тяжіє до чіткої ієрархічної системи з розподілом зон геополітичного впливу, тому поведінка держав у такій системі є дещо прогнозованою, адже сама структура системи міжнародних відносин визначає поведінку їі учасників. Баланс між полюсами гарантує стабільність та довготривалість самої системи. Цей баланс надає постійності характеру системи міжнародних відносин, чого не можна сказати про однополярну систему, в якій лише національні інтереси зумовлюють дії держав на міжнародній арені. І тут ідеться не про інтереси зовнішньої політики, а швидше про національні амбіції та політичний тиск.

Однополярний порядок міжнародної політики піддається флуктуаціям через відсутність стабільності всередині системи. Наддержава намагається вибудовувати світовий порядок за власним баченням, нехтуючи при цьому потребами самої системи. США не бажають бачити важливість України для Росії в економічному та геополітичному плані та підтримують вихід України із зони геополітичних інтересів Росії. Неореалісти критично ставляться до такої недалекоглядної політики Вашингтона щодо російсько-українського питання, вважаючи, що такі заяви та дії можуть підірвати могутність США. Тим більше США вже мають невдалий досвід такої політики на терені колишньої Югославії. Такі дії з боку єдиної наддержави призводять до глибокого незадоволення інших держав, таких як Росія. І це незадоволення лише зростатиме, що спонукатиме незадоволені держави виступити проти дій єдиної надпотуги й використати при цьому всі доступні можливості та інструменти. Розглядаючи стан анархії як ключову характеристику сучасної системи міжнародних відносин, Росія вважає, що не потребує дозволу з боку жодної іншої держави протистояти цій системі, адже дії окремих ії̈ учасників несуть загрозу її національній безпеці та позбавляють їі статусу рівноправного учасника у системі міжнародних відносин.

Непостійність, яка характерна для однополярної структури міжнародних відносин, вказує на неоднозначні перспективи розв'язання конфлікту між Україною та Росією. 3 моменту вторгнення Росії на територію України, окупації частини ї̈ території та початку збройного конфлікту на Сході нашої держави США та країни Західної Європи союзники по НАТО не змогли підтримати Україну у військовому плані, тобто вступити у військову конфронтацію з Росією з метою захисту України Захід не спромігся і це пояснюється передусім небажанням піддавати ризику співпрацю з Росією у сфері економіки та енергетики. Адже пряма конфронтація призвела б до глибокої енергетичної кризи в Європі, що вплинуло б негативно на розвиток західноєвропейських економік.

Тому найбільш рішучою дією США та країн Європи стало запровадження блоку санкцій, який навряд чи може вплинути на наміри Росії відмовитись від своїх національних інтересів в Україні. Адже за умови домінування у світі єдиної надпотуги - США та міжнародно-політичної ситуації у світі, яка складається не на користь Москви, до того ж є такою, що позбавлена чітких контурів майбутнього, Росія відчуває свою незахищеність як результат дії загроз з боку НАТО/США та $\mathrm{CC,}$ які впритул наближаються до їі кордонів. Тому єдиним виходом для Білокамінної залишається використання зброї з метою захисту її інтересів. Інші інструменти не вбачаються Москвою такими, які б можна було застосувати з метою протидії розширенню НАТО та ЄС на Схід. Застосування зброї стосовно України є неминучим, але такий крок не $€$ відповіддю на загрози з боку України, а швидше $€$ реакцією на політику розширення НАТО та розміщення військових баз Альянсу поблизу кордонів Російської Федерації.

Саме відсутність балансу в однополярній системі міжнародних відносин робить їі крихкою та нестабільною, адже більш слабкі держави з метою зміцнення власних позицій та захисту національних інтересів вживають різних заходів, аби підвищити рівень власної захищеності. Домінуючі позиції США у світі надають Вашингтону необмежені можливості для втручання у внутрішні справи інших держав із прагненням поширити демократичні цінності у тих країнах світу, де 3 позиції Білого дому вони відсутні, проте потреба у встановленні демократичних режимів $є$. Росію на початку 90 -х минулого століття не оминули процеси поширення демократичних цінностей, проте авторитаризм та прагнення до одноосібного керування великою державою переважили потребу у зміні політичного режиму, який і дотепер залишається авторитарним або режимом керованої демократії. Розуміючи, що процеси розширення НАTO та ЄС на Схід несуть із собою й поширення демократичних цінностей і таким чином Москва втрачає пояс геополітичних інтересів навколо iii кордонів, що може перетворитись на дугу 
демократії та верховенства закону, Кремль вдається до насильницьких засобів, аби протидіяти в майбутньому внутрішнім проблемам усередині Росії на кшталт вимог російським суспільством формування справді демократичної правової держави, де є місце правам людини, свободі ЗМІ тощо. Нині прийшов час, - вважає Білокамінна, коли США та країни Західної Свропи активно підтримують громадсько-політичні рухи Росії, що виступають за поширення демократичних цінностей у федерації, в такий спосіб дестабілізуючи країну загалом. Тому уряд Російської Федерації намагається щосили знищити цей жахливий для неї сценарій у зародку.

Цікаво зауважити, що К. Уолтц використовує іноді у своїх тезах термін «експансія» замість терміна «розширення» та вважає, що для США та НАТО політика розширення на Схід є ніяк не процесом поширення демократичних цінностей в ім'я миру, справедливості та благополуччя в усьому світі, а навпаки, процесом агресивної експансії, мета якої - встановлення тотального контролю над великими та середніми державами шляхом приходу до влади прозахідних демократичних режимів. Така агресивна політика й кидає виклик інтересам інших держав, зокрема Росії [3, с. 24]. Тому Москва всупереч наявній системі міжнародно-правових норм у 2014 році використала й продовжує використовувати вже 7 років поспіль насильницькі засоби для розв'язання життєво важливих питань їі національної безпеки [1]. Таким чином, анархічність однополярності призводить до неможливості держав узгоджувати між собою дії та скеровувати взаємодії. Одна єдина надпотуга діє винятково виходячи із власних інтересів національної безпеки, не беручи до уваги потреби інших. Це і призводить до необхідності великих та середніх держав захищати свої інтереси. 3 точки зору неореалізму проблема збройного протистояння в українсько-російських відносинах може бути розв' язана лише в один єдиний спосіб - відмова США/НАТО та ЄС від своєї політики розширення/експансії на Схід, створення буферної зони, яка фактично буде поясом геополітичних інтересів Росії, де вона гратиме роль великої держави, здатної формувати власний політичний, військовий, економічний, енергетичний та культурний простір. Таким чином, демократія тобто західні цінності, «будуть принесені в жертву» регіональній стабільності та безпеці.

Висновки. Кримська криза 2014 року та початок збройного російсько-українського протистояння викликано не лише реакцією Росії на події в Україні та зміною їі зовнішньополітичних орієнтирів, але й такими міжнародно-політичними чинниками, як: експансія демократичних цінностей з боку США та країн Західної Свропи на країни світу, які раніше входили до зони гео- політичної відповідальності Москви та прагнення Вашингтона вирішувати питання власної безпеки, не беручи до уваги інтереси великих та середніх держав сучасного світу, що породжує ще більшу анархічність міжнародної політики, конфліктність самої структури та спонукає інші держави до вжиття заходів протидії з метою підвищення рівня власної захищеності та забезпечення реалізації інтересів національної безпеки. В теорії неореалізму дії держав у системі міжнародних відносин оцінюються незалежно від їх ідеологічних характеристик. Отже, наміри Росії втрутитись у ситуацію, яка склалась наприкінці 2013 - на початку 2014 рр. в Україні, напряму витікають з їі національних інтересів. Незалежно від того, чи є Росія демократичною чи авторитарною державою, захист її елементарних інтересів в Україні є зрозумілим з точки зору теорії політичного неореалізму. Система міжнародних відносин - це сукупність одиниць - держав, які діють відповідно до своєї ролі у системі та їх можливостей/ресурсів. Система впливає на дії держав, у разі коли система є однополярною, то дії великих, середніх та малих держав є реакцією на дії світового гегемона та його сателітів. Цим і пояснюються дії Росії щодо України, яка вбачає проблему у використанні "української карти» для остаточної експансії демократичних цінностей на пояс геополітичних інтересів Росії з метою подальшого розширення демократії вже вглиб Росії і в такий спосіб підриву їі авторитарного політичного режиму, зміни влади та встановлення демократичного уряду, лояльного наддержаві - США. Виходячи з цього, Росія вимушена застосовувати насильницькі заходи в Україні з метою протидії політичній експансії із Заходу.

У біполярній або багатополярній системі міжнародних відносин існує чітка структура правил, яких прагнуть дотримуватись усі структурні одиниці - держави, і таким чином забезпечується стабільність та реалізація національних інтересів кожної держави або блоку держав. В однополярній державі така система правил відсутня, панує анархія, що посилює прагнення одного єдиного гегемона диктувати свої правила та нав'язувати свою волю іншим державам. Потреби та інтереси інших держав гегемона не цікавлять. Своєю чергою ці держави, занепокоєні зниженням рівня власної захищеності, вдаються до насильницьких дій, що і зробила Росія стосовно України в 2014 році та продовжує це робити вже 7 років поспіль.

Поведінка держав у відповідності до теорії політичного неореалізму повинна бути раціональною й приносити конкретні дивіденди. Такими дивідендами для Росії є забезпечення нею контролю над українськими трубопроводами з метою отримання стабільного доходу від експорту газу 
в Європу. Контролюючи ці трубопроводи, Росія може посилити свої політичні позиції не лиже на Європейському континенті, але й за його межами. Окрім цього, Росія не відчуває себе захищеною стратегічно на своїх південних морських кордонах, тому з моменту розпаду СРСР та утворення нових незалежних держав Москва розглядала різні сценарії повернення Криму «додому», поступово реалізовуючи їх та готуючи підгрунтя для військового вторгнення на півострів 3 метою анексії. Входження Криму до складу Російської Федерації закрило питання щодо російської військово-стратегічної присутності у Чорному морі - відомо, що Крим нині являє собою не «чорноморську перлину», а потужний військово-стратегічний й оборонний комплекс, основне завдання якого - контроль над Чорним морем та фактичне перетворення його на внутрішне море Росії та Туреччини. Ось тут і криється логічне пояснення анексії Росією Кримського півострову.

Таким чином, політичний неореалізм дає нам можливості збагнути поведінку держав в однополярній системі міжнародних відносин, зрозуміти їх цілі та мотивацію дій. А також чому держави надають перевагу насильницьким засобам, коли йдеться про потребу у підвищенні рівня їх захищеності.

Іншим важливим аспектом теорії політичного неореалізму є те, що ця теорія підходить для аналізу конфліктів між країнами, які мають обмежену кількість джерел прибутку, тобто економіка яких залежить від однієї статті доходу, наприклад Росія, економіка якої тримається лише на експорті енергоносіїв. Таким чином, коли йдеться про загрозу експорту, Росія вдається до жорсткої сили - відкритого збройного протистояння з Україною.

\section{Jimepamypa}

1. Mearsheimer J. Getting Ukraine Wrong. The New York Times. March, 13. URL: http:// www.midcoastforum.org/wp-content/uploads/ MearsheimerNYT.pdf.

2. Bock A., Henneberg I., \& Plank F. "If you compress the spring, it will snap back hard": The Ukrainian crisis and the balance of threat. International Journal. MARCH 2015. Vol. 70. The Past in International Statecraft. P. 101-109.

3. Kenneth N. Waltz. Theory of International Politics. Reading, Mass.: Addison-Wesley Publishing Co. 1979. Pp. iv +251 .

4. Mearsheimer J. Why the Ukraine Crisis Is the West's Fault: The Liberal Delusions That Provoked Putin. Foreign Affairs. 2014. URL: https://www. Foreignaffairs.Com/articles/russia-fsu/2014-08-18/ why-ukraine-crisis-west-s-fault.

\section{Анотація}

Баскакова А. С. Кримська криза та російсько-українська війна: погляд із позиції політичного неореалізму. - Стаття.

У статті проведено комплексний аналіз особливостей використання теоретико-концептуального та методологічного інструментарію такого наукового напряму в міжнародно-політичній науці, як політичний неореалізм, для дослідження Кримської кризи та початку українсько-російського збройного протистояння. Стверджується, що Кримська криза 2014 року та початок збройного російсько-українського протистояння викликані не лише реакцією Росії на події в Україні та зміною їі зовнішньополітичних орієнтирів, але й такими міжнародно-політичними чинниками, як: експансія демократичних цінностей 3 боку США та країн Західної Європи на країни світу, які раніше входили до зони геополітичної відповідальності Москви та прагнення Вашингтона вирішувати питання власної безпеки, не беручи до уваги інтереси інших держав сучасного світу, що породжує ще більшу анархічність міжнародної політики, конфліктність самої структури та спонукає інші держави до вжиття заходів протидії з метою підвищення рівня власної захищеності та забезпечення реалізації інтересів національної безпеки.

Особливої актуальності проблема дослідження набуває в зв'язку із потребою у концептуалізації протистояння між Україною та Росією з точки зору політичного неореалізму. Основна ідея полягає в тому, чи може втручання Росії у внутрішні справи пострадянських країн та порушення нею територіальної цілісності цих держав бути визнане легітимним з точки зору політичного неореалізму.

Метою дослідження є аналіз Кримської кризи та початку українсько-російського збройного протистояння 3 використанням такого наукового напряму в міжнародно-політичній науці, як політичний неореалізм.

Щодо окупації Криму та збройного протистояння на Сході України, то неореалісти використовують теорію «балансу загроз» для пояснення дій РФ. До прямого порушення норм міжнародного права з боку Москви призвели не лише неоімперські амбіції, а й бажання стримати розширення НАТО на схід, експансію демократичних цінностей 3 боку США на пострадянський простір. Незалежно від типу політичного режиму, захист інтересів Росії є зрозумілим 3 точки зору теорії політичного неореалізму: вона вбачає проблему для себе у використанні «української карти» для остаточної експансії демократичних цінностей на пояс геополітичних інтересів Росії 3 метою подальшого розширення демократії вже вглиб Росії і в такий спосіб підриву її авторитарного політичного режиму, зміни влади та встановлення демократичного уряду.

Ключові слова: політичний неореалізм, Кримська криза, російсько-українська війна, зона геополітичної відповідальності, анархічність сучасної системи міжнародних відносин, США/НАТО, ЄС. 


\section{Summary}

Baskakova A. S. The Crimean crisis and the RussianUkrainian war: a view from the perspective of political neorealism. - Article.

A comprehensive analysis of the peculiarities of the use of theoretical, conceptual and methodological tools of such a scientific field in international political science as political neorealism to study the Crimean crisis and the beginning of the Ukrainian-Russian armed confrontation was carried out in the article. It is claimed that the Crimean crisis (2014) and the beginning of the armed Russian-Ukrainian confrontation was caused not only by Russia's reaction to the events in Ukraine and changes in its foreign policy orientations. Also, by such international political factors as the expansion of democratic values by the United States and Western Europe to states that were a part of Moscow's geopolitical responsibility and Washington's desire to resolve its own security issues. Moreover, without taking into account the interests of other states in the modern world, which creates even more anarchy in international politics, conflicting of structure and encourages other states to take actions in order to increase the level of self-protection and ensure the realization of national security interests.

The problem of research becomes especially relevant in connection with the need to conceptualize the confrontation between Ukraine and Russia in terms of political neorealism. The basic idea is whether Russia's interference in the internal affairs of the post-Soviet countries and its violation of the territorial integrity of these states can be recognized as legitimate in terms of political neorealism.

The aim of the study is to analyze the Crimean crisis and the beginning of the Ukrainian-Russian armed confrontation using the scientific direction in international political science as political neorealism. Regarding the occupation of Crimea and the armed confrontation in Eastern Ukraine, the neorealists use the "threat balance" theory to explain the actions of Russia. Moscow's direct violation of international law was led not only by neo-imperial ambitions, but also by a desire to curb NATO's eastward expansion by expanding US democratic values into the post-Soviet space. Regardless of the type of political regime, the protection of Russia's interests is understandable from the point of view of the theory of political neorealism: it sees a problem in using the "Ukrainian card" for the final expansion of democratic values into Russia's geopolitical interests in order to further expand democracy deep into Russia and thus undermine its authoritarian political regime, change of power and establish a democratic government.

Key words: political neorealism, Crimean crisis, Russian-Ukrainian war, zone of geopolitical responsibility, anarchy of the modern system of international relations, USA/NATO, EU. 